\title{
KANDUNGAN KIMIA DARI LIMBAH LUMPUR INSTALASI PENGOLAHAN AIR MINUM UNTUK BETON GEOPOLIMER DENGAN XRF
}

\author{
Nuryanti, Ridha Arizal dan Dian Arrisujaya* \\ Program Studi Kimia, Universitas Nusa Bangsa \\ JL. K.H. Sholeh Iskandar Km. 4, Cimanggu, Tanah Sareal, Bogor 16166 \\ *e-mail: d1 anarrisujaya@gmail.com
}

\begin{abstract}
Chemical Containt of Waste Water Installation of Drinking Water Treatment for Geopolymer Concrete by XRF
\end{abstract}

\begin{abstract}
Preparation of geopolymer concrete from waste water installation of drinking water treatment (WIDWT) was manufactured in accordance with SNI. Specimen of size $5 \times 5 \times 5 \mathrm{~cm}$ cubes was used for the concretes. The mortar material consisted of binders, activator, aggregate (fine sand) and water (60\% of aggregate and $40 \%$ of activators and binders). The composition of the activator and binder mixture were $1: 2 ; 1: 1,5 ; 1: 1 ; 1.5: 1$; and 2: 1. The results of the comparison of binders $A$ and $B$ were 4.2: 1 and 6.5: 1. The binders were divided into 2 types: $A$ binder (sludge of WIDWT was dried with oven at $105^{\circ} \mathrm{C}$ for 24 hours) and B Binder (sludge of WIDWT was dried by kiln at $650^{\circ} \mathrm{C}$ for 6 hours). The highest compressive strength test was $10.00 \mathrm{MPa}$ on binder $A$ with the ratio of activator and binder 1: 1 and Si: Al ratio (4.2: 1). Binder B with a compressive strength of $9.87 \mathrm{MPa}$ with the ratio of activator and binder 1.5: 1 and Si: Al ratio (6.5: 1). Samples of IPAM sludge waste were tested by X-Ray Fluorescence (XRF), compressive strength testing of mortar geopolymer with Toni-Technik compressive strength test. The highest value of compressive strength appropriated to SNI 03-0691-1996 in class D which can be applied for City Park.
\end{abstract}

Keywords: geopolymer, WIDWT, XRF, activator, binder

\begin{abstract}
ABSTRAK
Pembuatan beton geopolimer dari limbah instalasi pengolahan air minum (IPAM) telah dilakukan. Beton geopolimer dibuat sesuai dengan SNI pembuatan mortar geopolimer dengan ukuran 5 x 5 x $5 \mathrm{~cm}$. Bahan mortar terdiri dari binder, larutan aktivator dan agregat (pasir halus) serta air dengan perbandingan 60\% (agregat) dan 40\%(aktivator dan binder). Parameter variasi campuran aktivator dan binder yaitu 1:2; 1:1,5; 1:1; 1,5:1; dan 2:1. Binder dibagi menjadi 2 jenis yaitu Binder A (lumpur IPAM yang dikeringkan dengan oven pada suhu $105^{\circ} \mathrm{C}$ selama 24 jam) dan Binder B (lumpur IPAM yang dikeringkan dengan tanur pada suhu $650^{\circ} \mathrm{C}$ selama 6 jam). Hasil perbandingan binder A dan B adalah 4,2:1 dan 6,5:1. Hasil uji kuat tekan tertinggi sebesar 10,00 Mpa pada binder A dengan perbandingan aktivator dan binder 1:1 dengan perbandingan Si:Al (4,2:1). Binder B dengan kuat tekan 9,87 Mpa dengan perbandingan aktivator dan binder 1,5:1 dengan perbandingan Si:Al (6,5:1). Sampel limbah lumpur IPAM diuji dengan X-Ray Flourescene (XRF), pengujian kuat tekan mortar geopolimer dengan alat uji kuat tekan merk Toni-Technik. Nilai kuat tekan tertinggi memasuki persyaratan mutu SNI 03-0691-1996 pada kelas D yang bisa diaplikasikan untuk taman kota.
\end{abstract}

Kata Kunci: geopolimer, IPAM, XRF, aktivator, binder

\section{PENDAHULUAN}

Proses pengolahan air bersih menggunakan koagulan seperti tawas dan Poli Aluminium Klorida (PAC) sebagai media penggumpal partikel-partikel halus yang tersuspensi menjadi gumpalangumpalan yang lebih besar (flok). Kumpulan flok yang terbentuk selanjutnya dipisahkan dengan cara sedimentasi dan filtrasi sehingga didapatkan air yang bersih dan sisanya dalam bentuk limbah padat berupa lumpur dibuang. Lumpur yang dibuang dan ditimbun ini masih mengandung aluminium sulfat (alum) dalam bentuk lumpur yang dapat diolah kembali menjadi alumina $\left(\mathrm{Al}_{2} \mathrm{O}_{3}\right)$ melalui proses pengambilan kembali /recovery (Mirwan, 2012).

Limbah lumpur pengolahan air minum pada proses koagulasi memiliki kandungan aluminium yang tinggi, karena pada proses koagulasi ditambahkan suatu garam aluminium sebagai koagulannya. Menurut Suherman (2003), limbah lumpur IPAM masih mengandung aluminium 
dalam bentuk $\mathrm{Al}(\mathrm{OH})_{3}$ yang berpotensi sebagai pencemar jika langsung dibuang ke sungai. Kadar aluminium lumpur IPAM yaitu 2241,48 mg/L (Awwaludin, 2016). Jika dilihat dari kadar aluminium yang cukup tinggi tersebut, maka seharusnya lumpur tersebut tidak boleh dibuang ke sungai karena sifat aluminium yang resisten dan umumnya tidak larut dalam keadaan $\mathrm{pH}$ netral (antara 6,0-8,0), di bawah asam $(\mathrm{pH}<6,0)$ atau alkali $(\mathrm{pH}>8,0)($ Az-zahra et al., 2014).

Lumpur IPAM masih mengandung sisa aluminium dari hasil proses koagulasi sebesar 2241,48 $\mathrm{mg} / \mathrm{L}$ dan mengandung kandungan $\mathrm{SiO}_{2}: \mathrm{Al}_{2} \mathrm{O}_{3}$ sebesar $49,11 \%$ : $29,45 \%$. Berdasarkan unsurnya, maka perbandingan Si:Al pada lumpur IPAM yaitu 1,5:1. Perbandingan Si:Al yang rendah yaitu $1: 1$ atau 2:1, dapat menghasilkan beton geopolimer yang baik (Nugteren et al., 2009).

Salah satu contoh pemanfaatan limbah lumpur pengolahan air minum pada bahan bangunan yaitu pembuatan beton. Beton yang terbuat dari limbah lumpur pengolahan air minum ini biasa disebut beton geopolimer. Kelebihan beton secara umum yaitu memiliki kuat tekan yang tinggi dan dapat direncanakan sesuai dengan keinginan, mudah dibentuk, tahan terhadap temperatur tinggi, biaya perawatan rendah, dapat dibuat dengan menggunakan bahan-bahan lokal, serta tahan terhadap cuaca (Cahyadi, 2013).

Geopolimer merupakan sintesis bahan-bahan produk sampingan seperti abu terbang (fly ash), abu kulit padi (ricehusk ash) dan lain-lain yang banyak mengandung silika dan alumina (prekursor) membentuk sebuah senyawa silikat alumina anorganik (Lloyd dan Ranga, 2010). Beton geopolimer merupakan beton yang material utamanya mengandung banyak silika dan alumina tinggi yang direaksikan dengan alkali aktivator. Proses pembentukan beton geopolimer terbentuk melalui proses polimerisasi bahan yang mengandung silikat dan alumina tinggi direaksikan dengan menggunakan alkali aktivator (polysilicate) menghasilkan ikatan polimer Si-O-Al, dengan ikatan polimer ini maka akan terbentuk padatan berupa amorf sampai semi kristal (Pujianto, 2013).

Beton geopolimer dapat dibuat dengan atau tanpa menggunakan semen. Beton geopolimer mulai diperkenalkan sebagai beton ramah lingkungan karena dapat mengurangi emisi $\mathrm{CO}_{2}$ akibat penggunaan semen Portland. Produksi tiap ton semen Portland, akan melepaskan hampir 1 ton $\mathrm{CO}_{2}$ ke atmosfer (Anwar, 2015). Beton geopolimer memiliki kelebihan yaitu jika material ini digunakan untuk mengganti penggunaan semen Portland, maka dapat mengurangi sekitar $80 \%$ emisi karbon dioksida ke atmosfer yang disebabkan oleh industri semen dan agregat (Davidovits, 1994).

Dalam pembuatan paving block dikenal dengan dua metode, yaitu metode konvensional (manual) dan metode mekanis. Metode konvensional adalah metode yang paling banyak digunakan oleh masyarakat karena lebih mudah dan tidak memerlukan biaya yang terlalu tinggi. Pembuatan paving block dengan cara konvensional ini biasanya menggunakan alat cetak paving yang disebut "gablokan". Alat ini masih menggunakan tenaga manusia (manual) dalam proses pemadatan sehingga kekompakan paving block yang dihasilkan bergantung pada tenaga orang yang memadatkannya. Mutu paving block yang dihasilkan dengan metode ini biasanya masuk ke dalam kelas mutu $\mathrm{C}$ dan D. Sementara itu, metode mekanis atau biasa disebut dengan metode press, menggunakan alat press paving yang harganya cukup mahal, sehingga hanya biasa digunakan oleh pabrik dengan skala sedang atau besar. Namun demikian, mutu paving block yang dihasilkan dengan metode ini lebih baik, yaitu antara mutu C hingga mutu A (Sherliana, 2016).

Bahan-bahan yang digunakan untuk paving block sama dengan bahan pembuatan beton seperti agregat (batu pecah, pasir) bahan pengikat hidrolis (semen) dan air. Seperti pada pembuatan beton lainnya, persyaratan yang diperlukan untuk agregat, semen dan air yang digunakan harus memenuhi persyaratan seperti tercantum pada spesifikasi bahanbahan beton (Adibroto, 2014). 
Bahan lain pembuatan paving block geopolimer yaitu alkali aktivator. Alkali aktivator merupakan bahan kimia yang digunakan untuk mengaktifkan prekusor sehingga dapat menghasilkan ikatan geopolimer yang kuat. Alkali mengaktifkan prekursor dengan mendisolusikan $\mathrm{SiO}_{2}$ dan $\mathrm{Al}_{2} \mathrm{O}_{3}$ ke dalam monomer $\mathrm{Si}(\mathrm{OH})_{4}$ dan $\mathrm{Al}(\mathrm{OH})_{4}$. Selama proses curing, monomermonomer tadi terkondensasi dan membentuk jaringan polimer tiga dimensi dan berikatan silang (Septia, 2011).

Beton geopolimer dibuat menggunakan $\mathrm{Na}_{2} \mathrm{SiO}_{3}$ (natrium silikat) dan $\mathrm{NaOH}$ (natrium hidroksida) sebagai alkali aktivator. Natrium silikat $\left(\mathrm{Na}_{2} \mathrm{SiO}_{3}\right)$ merupakan salah satu bahan tertua dan paling aman yang sering digunakan dalam industri kimia, hal ini dikarenakan proses produksi yang lebih sederhana. Natrium silikat mempunyai 2 bentuk, yaitu padatan dan larutan. Sodium silikat merupakan salah satu senyawa yang berperan dalam pembuatan beton geopolimer yang berwarna putih berbentuk gel dan apabila dilarutkan dalam air menghasilkan larutan alkali. Sodium silikat berperan penting untuk mempercepat reaksi polimerisasi (Arini et al, 2013).

\section{BAHAN DAN METODE}

\section{Bahan dan Alat}

Bahan-bahan yang digunakan yaitu binder (sampel limbah lumpur IPAM), pasir dan alkali aktivator yaitu larutan $\mathrm{NaOH}$ dan waterglass $\left(\mathrm{Na}_{2} \mathrm{SiO}_{3}\right.$ gel) dan aquadest. Peralatan yang digunakan yaitu peralatan gelas, oven Autonics TZN4W, tanur Thermo Scientifict, saringan 200 mesh, instrument $X$-Ray Fluoresence (XRF) PANalytical XVenus 200 minilab untuk menganalisis komposisi kimia lumpur

$\mathrm{Al}(\%)=\frac{\mathrm{ArAl} \times 2}{\mathrm{Mr} \mathrm{Al}_{2} \mathrm{O}_{3}} \times \% \mathrm{Al}_{2} \mathrm{O}_{3}$

IPAM dan Toni-Technik untuk pengujian kuat tekan paving block.

\section{Preparasi sampel limbah lumpur IPAM dan Pasir}

Limbah lumpur IPAM diambil dari PT Traya Tirta Cisadane. Lumpur IPAM tersebut ditampung dalam wadah dan dibiarkan mengendap agar terpisah antara lumpur dan air. Lumpur tersebut dikeringkan/dijemur dengan panas matahari selama 2-3 hari. Lalu dikeringkan menggunakan oven dengan suhu $105^{\circ} \mathrm{C}$ selama 24 jam dijadikan sebagai binder $\mathrm{A}$. setelah dikeringkan dengan oven, lumpur dikeringkan menggunakan tanur dengan suhu $650^{\circ} \mathrm{C}$ selama 6 jam dijadikan sebagai binder B. Lumpur IPAM yang sudah dikeringkan dihaluskan. Setelah halus, lumpur diayak menggunakan ayakan biasa, lalu lumpur diuji komposisi kimianya menggunakan XRF. Setelah itu, lumpur diayak dengan ayakan 200 mesh. Pasir yang digunakan adalah pasir Cimangkok yang berwarna hitam. Pasir dijemur dengan panas matahari selama 2-3 hari hingga kering. Untuk menghilangkan pasir yang masih kasar, pasir diayak menggunakan ayakan biasa hingga didapat tekstur pasir yang lebih halus.

\section{Analisis Komposisi Kimia Sampel (Lumpur IPAM)}

Komposisi lumpur IPAM yang sudah dikeringkan dengan oven dan tanur, dianalisis menggunakan instrumen $X$-Ray Fluorescence (XRF) PANalytical XVenus 200 minilab. Pengujian komposisi kimia lumpur kering menggunakan XRF, dilakukan dengan menimbang lumpur sebanyak 12 gram.

Hasil analisis instumen XRF berupa $\%$ berat senyawa oksida. Oleh karena itu, perlu perhitungan dengan menggunakan faktor kimia untuk mendapat hasil \% berat sebagai unsurnya. Untuk mendapatkan kandungan $\mathrm{Si}$ dari $\mathrm{SiO}_{2}$, maka dapat dihitung dengan rumus:

$$
\mathrm{Si}(\%)=\frac{\mathrm{ArSi}}{\mathrm{MrSiO} 2} \times \% \mathrm{SiO} 2
$$

Keterangan :

$\begin{array}{ll}\mathrm{Si}(\%) & =\% \text { berat } \mathrm{Si} \\ \mathrm{ArSi} & =\text { Massa atom relatif } \mathrm{Si}(28,09)\end{array}$ 
$\mathrm{Mr} \mathrm{SiO}_{2}=$ Massa molekul relatif $\mathrm{SiO}_{2}$ $(60,09)$

$\% \mathrm{SiO}_{2}=$ Kadar $\mathrm{SiO}_{2}$ dari hasil analisis $\mathrm{XRF}$

$\mathrm{Al}(\%)=\%$ berat $\mathrm{Al}$

$\mathrm{Ar} \mathrm{Al}=$ Massa atom relatif $\mathrm{Al}$ (27)

$\mathrm{Mr} \mathrm{Al}_{2} \mathrm{O}_{3}=$ Massa molekul relatif $\mathrm{Al}_{2} \mathrm{O}_{3}$ (102)

$\% \mathrm{SiO}_{2}=\operatorname{Kadar} \mathrm{Al}_{2} \mathrm{O}_{3}$ dari hasil analisis $\mathrm{XRF}$

\section{Pembuatan Paving block Geopolimer (SNI No. 03-6825-2002)}

Benda uji yang digunakan dalam penelitian ini adalah paving block geopolimer. Paving block merupakan salah satu jenis mortar yang telah banyak digunakan. Pengujian dilakukan dengan membuat paving block berukuran $5 \mathrm{~cm} \mathrm{x}$ $5 \mathrm{~cm} \times 5 \mathrm{~cm}$ sesuai dengan SNI pembuatan mortar geopolimer yaitu SNI No. 03-68252002. Bahan mortar terdiri dari binder, larutan akivator dan agregat (pasir halus) dan air. Urutan proses pencampuran pembuatan paving block yaitu binderaktivator-pasir-air.

Binder dibagi menjadi 2 jenis yaitu Binder A dan Binder. Binder A merupakan lumpur Instalasi Pengolahan Air Minum yang dikeringkan dengan oven pada suhu $105^{\circ} \mathrm{C}$ selama 24 jam. Binder B merupakan lumpur Instalasi Pengolahan Air Minum yang dikeringkan oven pada suhu $105^{\circ} \mathrm{C}$ selama 24 jam, kemudian dikeringkan kembali dengan tanur pada suhu $650^{\circ} \mathrm{C}$ selama 6 jam.

Aktivator dibuat dengan melarutkan $\mathrm{NaOH}$ ke dalam air dengan molaritas $14 \mathrm{M}$. Penggunaan $\mathrm{NaOH}$ dengan konsentrasi tinggi dapat meningkatkan nilai kuat tekan geopolimer. Setelah itu, larutan $\mathrm{Na}_{2} \mathrm{SiO}_{3}$ dicampurkan dengan larutan $\mathrm{NaOH} 14 \mathrm{M}$. Perbandingan berat campuran $\mathrm{Na}_{2} \mathrm{SiO}_{3}$ dan $\mathrm{NaOH}$ yaitu 1,5:1 (Ramdhani, 2016).

Paving block dibuat dengan perbandingan $60 \%$ agregat (pasir halus) dan $40 \%$ campuran aktivator dan binder (Ramdhani, 2016). Campuran antara aktivator dan binder dibuat bervariasi yaitu $1: 2 ; 1: 1,5 ; 1: 1 ; 1,5: 1 ; 2: 1$. Campuran yang telah homogen, dicetak pada cetakan yang telah disediakan yaitu berukuran $5 \mathrm{~cm}$ x $5 \mathrm{~cm} \times 5 \mathrm{~cm}$, lalu campuran dipadatkan.
Hasil cetakan dioven dengan suhu $90^{\circ} \mathrm{C}$ selama 18 jam (Ramdhani, 2016). Kemudian hasil cetakan dikeluarkan dari oven dan dikering-anginkan. Setelah dingin, paving block dikeluarkan dari cetakan, lalu dilakukan pengujian kuat tekan beton.

\section{Analisis Kuat Tekan}

Paving block yang telah dicetak diuji kuat tekannya dengan menggunakan alat uji kuat tekan merk Toni-Technik. Paving block diletakkan pada alat diantara dua penjepit atas dan bawah. Paving block dijepit secara manual sehingga permukaan atas dan bawahnya menyentuh dengan alat. Mesin penguji kuat tekan dinyalakan, hingga mortar hancur dan angka yang keluar pada alat berupa satuan tekanan dicatat. Hasil pengujian kuat tekan beton geopolimer dalam bentuk paving block yang dihasilkan dibandingkan dengan persyaratan mutu paving block yaitu pada SNI No.03-0691-1996.

\section{HASIL DAN PEMBAHASAN}

\section{Hasil Analisis XRF pada Bahan Baku}

Komposisi senyawa oksida bahan baku diuji menggunakan instrumen XRF untuk mengetahui perbandingan $\mathrm{Si}: \mathrm{Al}$ pada lumpur IPAM kering oven dan tanur, setelah itu dihitung dalam bentuk unsurnya (Tabel 1).

Kandungan Si dan Al (\%) dari oksidanya dapat dihitung dengan menggunakan faktor kimia. Perbandingan Si:Al lumpur yang telah dikeringkan di oven dengan suhu $105^{\circ} \mathrm{C}$ selama 24 jam memberikan perbandingan yang cukup rendah yaitu 27,70\%:9,67\% (2,86:1). Perbandingan $\mathrm{Si}$ Al lumpur yang telah dikeringkan di tanur dengan suhu $650^{\circ} \mathrm{C}$ selama 6 jam memberikan perbandingan yang lebih tinggi daripada lumpur kering oven yaitu $33,60 \%: 8,12 \%$ (4,14:1). Perbandingan Si:Al yang rendah yaitu $1: 1$ atau $2: 1$, dapat menghasilkan mortar geopolimer yang baik, karena menunjukkan struktur amorf dan ukuran partikel bahan baku (contohnya fly ash) yang baik (Nugteren et al, 2009). 


\section{Mutu Paving block Geopolimer}

Mutu paving block dapat dilihat berdasarkan hasil kuat tekan paving block. Hasil Kuat tekan paving block dapat dipengaruhi oleh pengaruh perbandingan $\mathrm{Si}: \mathrm{Al}$, larutan alkali aktivator yang digunakan dan perbandingan aktivator: binder.

\section{Hasil Uji Kuat Tekan Paving block}

Paving block yang direkomendasikan adalah paving block nomor 3 dengan perbandingan aktivator: binder 1:1 dan nomor 9 dengan perbandingan aktivator: binder 1,5:1. Paving block nomor 3 menghasilkan nilai kuat tekan rata-rata sebesar $10,00 \mathrm{MPa}$ dan kuat tekan minimal sebesar 9,60 MPa. Paving block nomor 9 menghasilkan nilai kuat tekan rata-rata sebesar 9,78 $\mathrm{MPa}$ dan kuat tekan minimal sebesar 9,60. Paving block dengan nilai rata-rata $10,00 \mathrm{MPa}$ dan nilai minimum 8,5 $\mathrm{MPa}$, memasuki persyaratan mutu paving block kelas D. Oleh karena itu, paving block tersebut dapat digunakan untuk taman kota. Hal ini dikarenakan berdasarkan metode pembuatannya, mutu paving block yang dihasilkan dengan metode konvensional atau manual hanya masuk ke kelas $\mathrm{C}$, karena dengan metode tersebut mutu paving block biasanya masuk ke dalam kelas mutu $\mathrm{C}$ dan D. Sementara itu, paving block yang dihasilkan dengan metode mekanis atau biasa disebut dengan metode press biasanya masuk ke dalam kelas antara mutu $\mathrm{C}$ hingga mutu $\mathrm{A}$ (Sherliana, 2016).

Adapun 8 variasi paving block lainnya, diantaranya 6 variasi paving block memasuki persyaratan mutu bata beton untuk pasangan dinding sesuai SNI 03-0349-1989. Sisanya, 2 variasi paving block tidak memenuhi persyaratan paving block, maupun persyaratan mutu bata beton untuk pasangan dinding (Tabel 2). Paving block dengan hasil uji kuat tekan optimum 10,00 MPa jika dibandingkan dengan standar mutu bata beton untuk pasangan dinding (bata beton pejal), memasuki persyaratan mutu kelas I dan Paving block dengan hasil uji kuat tekan optimum 9,78 memasuki persyaratan mutu kelas II.

Tabel 1. Komposisi Senyawa Oksida dan Unsur Bahan Baku (Lumpur IPAM)

\begin{tabular}{|c|c|c|c|c|}
\hline \multirow[t]{2}{*}{ Senyawa } & \multicolumn{2}{|c|}{$\begin{array}{c}\text { Konsentrasi (\% berat) } \\
\text { Lumpur kering oven } 105^{\circ} \mathrm{C}, \\
24 \text { jam }\end{array}$} & \multicolumn{2}{|c|}{$\begin{array}{c}\text { Konsentrasi }(\% \text { berat }) \\
\text { Lumpur kering tanur } \\
650^{\circ} \mathrm{C}, 6 \text { jam }\end{array}$} \\
\hline & Oksida (\%) & Unsur $(\%)$ & Oksida (\%) & Unsur (\%) \\
\hline $\mathrm{SiO}_{2}$ & 59,25 & 27,70 & 71,87 & 33,60 \\
\hline $\mathrm{Al}_{2} \mathrm{O}_{3}$ & 18,27 & 9.67 & 15,33 & 8,12 \\
\hline $\mathrm{Fe}_{2} \mathrm{O}_{3}$ & 7,63 & 5,34 & 5,60 & 3,92 \\
\hline $\mathrm{CaO}$ & 1,25 & 0,89 & 0,93 & 0,66 \\
\hline $\mathrm{MgO}$ & 0.70 & 0,42 & 0,64 & 0,39 \\
\hline $\mathrm{Na}_{2} \mathrm{O}$ & 1,097 & 0,81 & 1,135 & 0,84 \\
\hline $\mathrm{K}_{2} \mathrm{O}$ & 0,706 & 0,59 & 0,638 & 0,53 \\
\hline
\end{tabular}

Tabel 2. Persyaratan Mutu Bata Beton untuk Pasangan Dinding

\begin{tabular}{lcccccccccc}
\hline & & \multicolumn{3}{c}{$\begin{array}{c}\text { Tingkat mutu bata } \\
\text { beton pejal }\end{array}$} & \multicolumn{4}{c}{$\begin{array}{c}\text { Tingkat mutu bata } \\
\text { beton berlubang }\end{array}$} \\
\cline { 2 - 9 } & Satuan fisis & I & II & III & IV & I & II & III & IV \\
\hline $\begin{array}{l}\text { Kuat tekan } \\
\text { bruto* rata-rata } \\
\text { min. }\end{array}$ & $\mathrm{MPa}$ & 10 & 7 & 4 & 2,5 & 7 & 5 & 3,5 & 2 \\
\hline $\begin{array}{l}\text { Kuat tekan } \\
\text { bruto masing- } \\
\text { masing benda } \\
\text { uji min. }\end{array}$ & $\mathrm{MPa}$ & 9 & 6,5 & 3,5 & 2,1 & 6,5 & 4,5 & 3 & 1,7 \\
\hline
\end{tabular}

(Sumber : SNI 03-0349-1989, SNI bata beton untuk pasangan dinding) 


\section{Pengaruh Perbandingan Si:Al}

Perbandingan Si:Al awal yaitu pada binder/lumpur yang telah dikeringkan di oven dengan suhu $105^{\circ} \mathrm{C}$ selama 24 jam memberikan perbandingan yang cukup rendah yaitu $27,70 \%: 9,67 \% \quad(2,86: 1)$. Perbandingan Si:Al lumpur yang telah dikeringkan di tanur dengan suhu $650^{\circ} \mathrm{C}$ selama 6 jam memberikan perbandingan yang lebih tinggi daripada lumpur kering oven yaitu $33,60 \%: 8,12 \%(4,14: 1)$.

Gambar 1 menunjukkan bahwa hasil kuat tekan yang optimum terdapat pada paving block nomor 3 yang memberikan nilai kuat tekan rata-rata tertinggi yaitu sebesar 10,00 MPa pada perbandingan $\mathrm{Si}: \mathrm{Al}=4,2: 1$. kemudian turun secara drastis sebesar 78,60\% pada nomor 4 menjadi 2,14 MPa dengan perbandingan $\mathrm{Si}: \mathrm{Al}=4,9: 1$. Semakin tinggi perbandingan $\mathrm{Si}: \mathrm{Al}$, maka semakin rendah nilai kuat tekan yang diperoleh. Hal ini dikarenakan semakin tinggi perbandingan $\mathrm{Si}: \mathrm{Al}$ akan menghasilkan geopolimer yang kurang baik dengan menghasilkan nilai kuat tekan yang rendah begitupun sebaliknya
(Nugteren et al., 2009). Namun, pada paving block nomor 5 mengalami kenaikan menjadi $5,84 \mathrm{MPa}$.

Gambar 2 menunjukkan bahwa hasil kuat tekan yang optimum terdapat pada paving block nomor 9 yang memberikan nilai kuat tekan rata-rata tertinggi yaitu sebesar 9,78 $\mathrm{MPa}$ pada perbandingan $\mathrm{Si}: \mathrm{Al}=6,5: 1$. Kemudian turun secara drastis pada nomor 10 sebesar 78,53\% menjadi 2,10 MPa dengan perbandingan $\mathrm{Si}: \mathrm{Al}=7,3: 1$. Semakin tinggi perbandingan $\mathrm{Si}: \mathrm{Al}$, maka semakin rendah nilai kuat tekan yang diperoleh. Hal ini dikarenakan semakin tinggi perbandingan Si:Al, akan menghasilkan geopolimer yang kurang baik dengan menghasilkan nilai kuat tekan yang rendah begitupun sebaliknya (Nugteren et al., 2009). Perbedaannya yaitu pada paving block berbahan dasar binder A sudah mencapai nilai optimum pada perbandingan aktivator dan binder 1:1, sedangkan paving block berbahan dasar binder $\mathrm{B}$ baru mencapai nilai kuat tekan optimum pada perbandingan aktivator:binder $1: 1,5$.

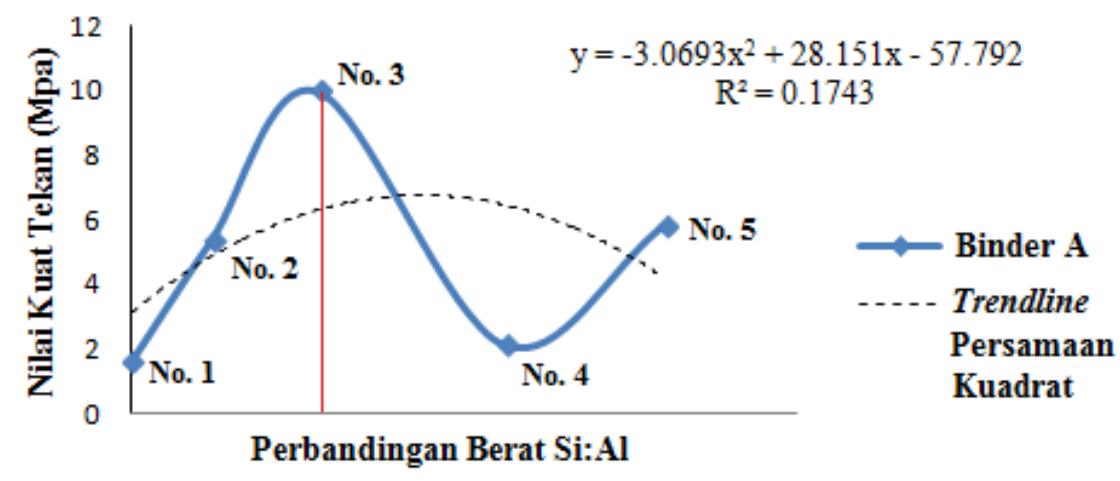

Gambar1. Trendline Persamaan Kuadrat Paving Block Binder A

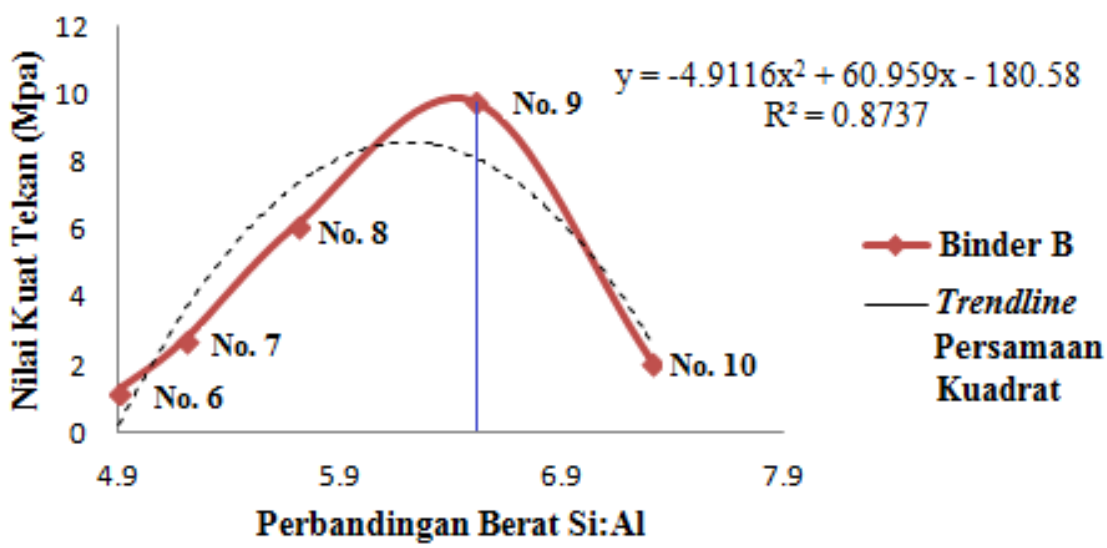

Gambar 2. Trendline Persamaan Kuadrat Paving Block Binder B 


\section{Pengaruh Larutan Alkali Aktivator dan Perbandingan Aktivator : Binder}

Penggunaan larutan $\mathrm{NaOH} 14 \mathrm{M}$ sebagai alkali aktivator dapat menghasilkan nilai kuat tekan yang lebih besar jika dibandingkan dengan beton geopolimer dengan molaritas yang rendah. Hal ini dikarenakan semakin tinggi konsentrasi $\mathrm{NaOH}$ yang digunakan, semakin banyak jumlah mol $\mathrm{OH}$ pada reaksi, sehingga ikatan pada reaksi geopolimerisasi menjadi sempurna (Ekaputri dan Triwulan, 2013). Selain $\mathrm{NaOH}$, penelitian ini juga menggunakan $\mathrm{Na}_{2} \mathrm{SiO}_{3}$ gel (waterglass) dengan spesifikasi teknis yang dibeli dari toko kimia. Komposisi teknis hasil analisis $\mathrm{Na}_{2} \mathrm{SiO}_{3}$ gel dengan menggunakan AAS diperoleh hasil kadar $\mathrm{NaOH}$ sebesar 22,0\%, $\mathrm{SiO}_{2}$ sebesar $46,0 \%, \mathrm{H}_{2} \mathrm{O}$ sebesar $19,3 \%$ dan senyawa lain sebesar 12,7\% (Swastika, 2010). Konsentrasi $\mathrm{NaOH}$ yang tinggi yaitu $14 \mathrm{M}$ dan dengan rasio perbandingan $\mathrm{Na}_{2} \mathrm{SiO}_{3}$ gel dan $\mathrm{NaOH}$ 1,5:1 memberikan nilai kuat tekan paling tinggi pada penelitian

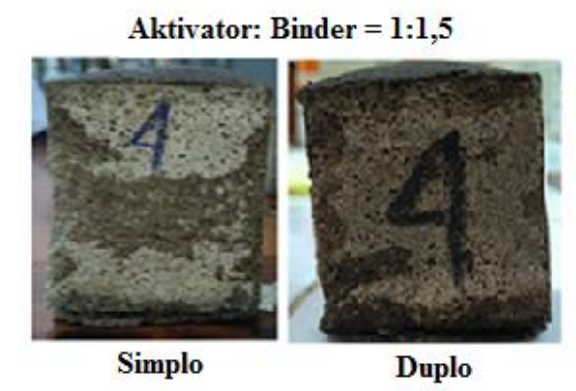

sebelumnya yaitu sebesar 20,21 $\mathrm{MPa}$ (Ramdhani, 2016). Jumlah berat aktivator dan binder/lumpur, dijadikan sebagai variabel bebas, sedangkan konsentrasi $\mathrm{NaOH}, \quad$ jumlah perbandingan $\mathrm{Na}_{2} \mathrm{SiO}_{3}$ gel : $\mathrm{NaOH}$, jumlah berat pasir, suhu dan waktu curing dijadikan variabel tetap.

Bentuk fisik paving block nomor 4 dan 5 (berbahan dasar binder A), dan 10 (berbahan dasar binder B) terlihat menggembung dan memiliki pori yang terbuka (Gambar 3). Ada dua macam pori yaitu pori terbuka dan tertutup. Pori terbuka yaitu pori yang bersifat permeable (dapat ditembus, baik oleh udara ataupun air). Pori tertutup adalah pori yang bersifat impermeable (tidak dapat ditembus). Pori yang tertutup lebih baik dari pori yang terbuka karena pori yang tertutup memiliki tekanan hidrostatis yang menambah kuat tekan beton dan terhindar dari retak, sedangkan pori yang terbuka membuat beton menjadi keropos dan dapat menurunkan kuat tekan beton (Ekaputri et al., 2007).

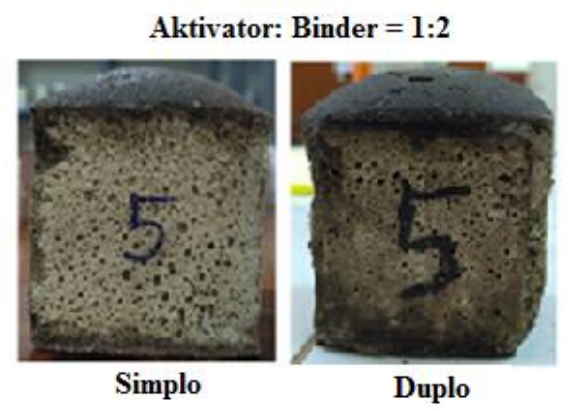

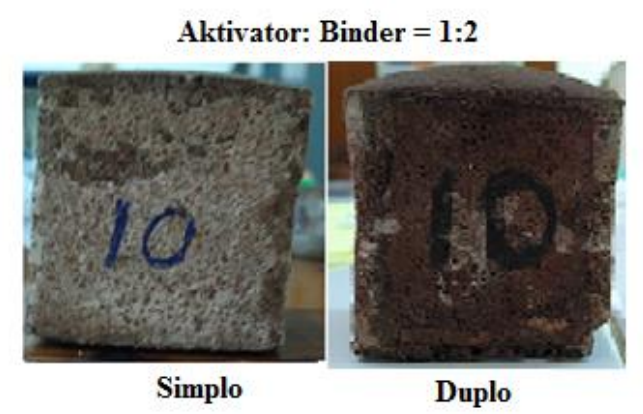

Gambar 3. Paving Block yang Menggembung dan Memiliki Pori Terbuka 
Bentuk paving block yang menggembung dan memiliki pori yang terbuka disebabkan karena jumlah aktivator lebih banyak daripada binder/lumpur, sehingga lambat laun paving block tersebut akan mengalami keretakan karena terjadi reaksi samping sebagai berikut.

$2 \mathrm{NaOH}_{(\mathrm{s})} \longrightarrow \mathrm{Na}_{2} \mathrm{O}_{(\mathrm{s})}+\mathrm{H}_{2} \mathrm{O}_{(\mathrm{l})}$ $\mathrm{Na}_{2} \mathrm{O}_{(\mathrm{s})}+\mathrm{CO}_{2}(\mathrm{~g}) \longrightarrow \mathrm{Na}_{2} \mathrm{CO}_{3(\mathrm{~s})}$

Larutan $\mathrm{NaOH}$ tidak mengion menjadi $\mathrm{Na}^{+}$dan $\mathrm{OH}^{-}$, tetapi mengurai menjadi $\mathrm{Na}_{2} \mathrm{O}$ (berwujud serbuk putih) dan $\mathrm{H}_{2} \mathrm{O}$. Air inilah yang mengisi ruang pada paving block. Pada saat dilakukan curing, air menguap sehingga meninggalkan lubang atau pori terbuka pada paving block dan mengakibatkan mudah retak dan rapuh. Kemudian $\mathrm{Na}_{2} \mathrm{O}$ yang dihasilkan mudah bereaksi dengan $\mathrm{CO}_{2}$ di udara membentuk $\mathrm{Na}_{2} \mathrm{CO}_{3}$ yang merupakan suatu kristal jarum putih yang menimbulkan warna putih pada paving block (Arizal, 2016).

Paving block berbahan dasar lumpur IPAM kering oven mencapai nilai kuat tekan optimum pada perbandingan aktivator : binder (1:1). Sedangkan paving block berbahan dasar lumpur IPAM kering tanur mencapai nilai kuat tekan optimum pada perbandingan aktivator : binder $(1,5: 1)$. Dari data tersebut, lumpur kering tanur membutuhkan jumlah aktivator lebih banyak daripada lumpur IPAM kering oven. Hal ini dikarenakan pada lumpur IPAM kering tanur, berbagai bahan pelarut, senyawa organik dan unsur lain seperti karbon dan sulfur hilang dan hanya tersisa senyawa anorganiknya saja sehingga bahan dasar lumpur kering tanur ini membutuhkan jumlah aktivator yang lebih banyak (Pujianto et al., 2013).

Proses polimerisasi juga dapat mempengaruhi hasil uji kuat tekan. Proses polimerisasi terdiri dari dari dua tahap yaitu proses disolusi yang diikuti proses polikondensasi. Pada proses disolusi menghasilkan monomer silikat $\mathrm{Si}(\mathrm{OH})^{4-}$ dan ion aluminat $\mathrm{Al}(\mathrm{OH})^{4-}$. Untuk mencapai disolusi yang sempurna diperlukan larutan alkali aktivator yang mencukupi (Pujianto, 2013).

\section{KESIMPULAN}

Lumpur IPAM yang merupakan lumpur hasil koagulasi dapat dijadikan sebagai bahan baku alternatif pembuatan geopolimer dalam bentuk mortar jenis paving block karena mengandung $\mathrm{Al}$ dan $\mathrm{Si}$ yang tinggi. Paving block berbahan dasar binder A memiliki nilai kuat tekan tertinggi sebesar 10,00 $\mathrm{MPa}$ pada variasi perbandingan aktivator : binder (1:1) dengan perbandingan Si:Al (4,2:1). Paving block berbahan dasar binder $\mathrm{B}$ memiliki nilai kuat tekan tertinggi sebesar 9,78 $\mathrm{MPa}$ pada variasi perbandingan aktivator : binder $(1,5: 1)$ dengan perbandingan Si:Al $(6,5: 1)$. Paving block dengan nilai kuat tekan tertinggi $10,00 \mathrm{MPa}$ dan 9,78 $\mathrm{MPa}$ memasuki persyaratan mutu $D$ sesuai dengan SNI 03-0691-1996, dapat digunakan sebagai paving block taman kota. Terdapat 8 Paving block yang tidak memenuhi persyaratan mutu paving block, 6 paving block memasuki persyaratan mutu bata beton untuk pasangan dinding sesuai dengan SNI 03-0349-1989, 2 sisanya tidak memenuhi persyaratan manapun. Paving block dengan hasil uji kuat tekan optimum $10,00 \mathrm{MPa}$ dan 9,78 $\mathrm{MPa}$, jika dibandingkan dengan standar mutu bata beton untuk pasangan dinding, berturutturut memasuki persyaratan mutu kelas I dan II.

\section{DAFTAR PUSTAKA}

Adibroto, F. 2014. Pengaruh Penambahan Berbagai Jenis Serat Pada Kuat Tekan Paving block. Jurnal Rekaya Sipil Teknik Sipil Politeknik Negeri Padang. Vol. No. 1 Febuari 2014 ISSN : 1858-2133. Padang.

Anwar, S. 2015. Pemanfaatan Serat Batang Pohon Pisang dalam Sintesi Material Hibrida Berbasis Geopolimer Abu Layang Batu Bara. Skripsi. Universitas Negeri Semarang.

Arini, R.N., Triwulan dan J.J. Ekaputri. 2013. Pasta Ringan Geopolimer Berbahan Dasar Lumpur Bakar Sidoarjo dan Fly Ash Perbandingan 
3:1 dengan Tambahan Powder dan Serat Alam. Jurnal Teknik Pomits Vol. 1. No. 1, (2013) : 1-5. Surabaya.

Arizal, R. 2016. Penelitian Geopolimer Kimia UNB Kerjasama dengan PT Antam UBPE Pongkor. Penelitian tidak diterbitkan. Universitas Nusa Bangsa. Bogor.

Az-zahra, S., Rachmawati, S.DJ., dan Eka, W. 2014. Karakteristik Kualitas Air Baku dan Lumpur sebagai Dasar Perencanaan Instalasi Pengolahan Lumpur IPA Badak Singa PDAM Tirtawening. Jurnal Rekayasa Lingkungan. ITENAS. Bandung.

Awaludin, A. 2016. Aplikasi Tawas Cair Reovery sebagai Koagulan Limbah Cair Industri Perisa Minuman. Skripsi. Universitas Nusa Bangsa. Bogor.

Badan Standarisasi Nasional. 1989. SNI 030349-1989: Bata Beton Untuk Pasangan Dinding.

Badan Standarisasi Nasional. 1996. SNI 030691-1996: Bata Beton (Paving block).

Badan Standarisasi Nasional. 2002. SNI 036825-2002: Metode Pengujian Kuat Tekan Mortar Semen Portland untuk Pekerjaan Sipil.

Cahyadi, D. 2013. Sifat Mekanik dan Durabilitas Polypropylene Fiber Reinforced Geopolymer Concrete (PFRGC). Jurnal Teknik Sipil Magister Teknik Sipil Universitas Sebelas Maret Vol. No. 1 Oktober 2013 ISSN : 2339-0271. Surakarta.

Davidovits, J. 1994. Global Warming IMPact on the Cement and Aggregates Industries, World Resource Review, 6(2), 263-278. Saint-Quentin.
Ekaputri, J.J., Triwulan, dan Oktavina, D. 2007. Sifat Mekanik Beton Geopolimer Berbahan Dasar Fly Ash Jawa Powder Paiton Sebagai Material Alternatif. Jurnal PONDASI. Vol. 13 No. 2, Desember 2007. ISSN: 0853-814X. Surabaya.

Ekaputri, J. J. dan Triwulan. 2013. Sodium Sebagai Aktivator Fly Ash, Trass dan Lumpur Sidoardjo dalam Beton Geopolimer. Jurnal Teknik Sipil. Jurnal Teoritis dan Terapan Bidang Rekayasa Sipil Vol. 20 No. 1, April 2013 ISSN : 0853-2982. Surabaya.

Mirwan, A. 2012. Pemanfaatan Kembali Limbah Padat Lumpur PDAM Untuk Penjernihan Air dari Sungai Martapura Kalimantan Selatan. Jurnal Teknik Kimia. Universitas Lambung Mangkurat. Kalimantan Selatan.

Nugteren, H.W, V.C.L. Butselaar-Orthlieb dan M. Izquiredo. 2009. High Strength Geopolymers Produced From Coal Combustion Fly Ash. Global NEST Journal, Vol 11. No 2, pp 155-161. 2009. Yunani.

Pujianto, A. Anzila N. A., Martyana D.C., dan Hendra. 2013. Kuat Tekan Beton Geopolimer dengan Bahan Utama Bubuk Lumpur Lapindo dan Kapur. Tugas Akhir. Universitas Muhammadiyah. Yogyakarta.

Ramdhani, S. A. 2016. Pengaruh Komposisi Kaolin dalam Pembuatan Mortar Geopolimer Berbahan Dasar Tailing Pertambangan Emas. Skripsi. Universitas Nusa Bangsa. Bogor.

Swastika, N. 2010. Analisis Ketahanan Beton Geopolimer Berbahan Abu Terbang dan Berbahan Metakaolin Terhadap Paparan Air Laut ASTM. Tesis. Universitas Indonesia. Depok.

Septia, P. (2011). Studi Literatur Pengaruh Konsentrasi $\mathrm{NaOH}$ dan Rasio 
$\mathrm{NaOH}: \mathrm{Na}_{2} \mathrm{SiO}_{3}$, Rasio Air/Prekursor Suhu Curing, Dan Jenis Prekursor Terhadap Kuat Tekan Beton Geopolimer. Skripsi. Universitas Indonesia.

Sherliana. 2016. Studi Kuat Tekan Paving block dengan Campuran Tanah, Semen dan $\mathrm{Abu}$ sekam padi Menggunakan Alat Pemadat
Modifikasi. Skripsi. Universitas Lampung. Bandar Lampung. 